\title{
Two new species of Zetzellia Oudemans (Acari: Stigmaeidae) that threaten the concept of genera: disgeneric marriage?
}

\author{
FABIO A. HERNANDES ${ }^{1,2}$ \& REINALDO J.F. FERES ${ }^{2}$ \\ ${ }^{1}$ Universidade Estadual Paulista Instituto de Biociências, Letras e Ciências Exatas IBILCE/ UNESP; Rua \\ Cristóvão Colombo, 2265, Jardim Nazareth, São José do Rio Preto, São Paulo, Brazil. 15054-000; Depto. \\ Zoologia e Botânica.fabio_akashi@yahoo.com.br, reinaldo@ibilce.unesp.br \\ ${ }^{2}$ Programa de Pós-Graduação-Biologia Animal, Unesp, campus de São José do Rio Preto, São Paulo, Brazil.
}

\begin{abstract}
Two new species of Zetzellia Oudemans, Z. agistzellia sp. n. and Z. quasagistemas sp. n., are described from rubber trees of northwestern São Paulo State, Brazil. Females have clear features of Zetzellia, whereas males resemble Agistemus in some characters. Immatures are also described. The discovery of these species raises some problems concerning generic concepts in Stigmaeidae. Since features of different genera are present in the same species, the authors suggest that the scope of those genera should be reviewed.
\end{abstract}

Key words: taxonomy; systematics; Zetzellia; Hevea brasiliensis; predators.

\section{Introduction}

Stigmaeidae is the second most numerous family of predatory mites found on plants, after Phytoseiidae (Santos \& Laing 1985). Some species have been used in biological control of plant pests. According to Ferla and Moraes (2003), Agistemus floridanus Gonzalez may be more important than other predators in controlling rubber tree pests. The stigmaeids commonly found on rubber trees of the Brazilian states of Mato Grosso and São Paulo belong to the genera Agistemus Gonzalez and Zetzellia Oudemans (Feres 2000, Feres et al. 2002, Ferla \& Moraes 2002).

Numbers of dorsal setae and shields are characters commonly used to classify different genera among stigmaeids (Gonzalez 1965, Summers 1966). The most noticeable feature that distinguishes Agistemus from Zetzellia is that the former has setae $d 2$ born on the hysterosomal plate, whereas in Zetzellia those setae are set on small platelets. 